\title{
High-throughput genotyping of wheat-barley amphiploids utilising diversity array technology (DArT)
}

Almudena Castillo ${ }^{1}$, María C Ramírez ${ }^{1}$, Azahara C Martín ${ }^{1}$, Andrzej Kilian², Antonio Martín ${ }^{1}$ and Sergio G Atienza ${ }^{1 *}$

\begin{abstract}
Background: Hordeum chilense, a native South American diploid wild barley, is one of the species of the genus Hordeum with a high potential for cereal breeding purposes, given its high crossability with other members of the Triticeae tribe. Hexaploid tritordeum ( $x$ Tritordeum Ascherson et Graebner, $2 n=6 \times=42, A A B B H^{c h} H^{c h}$ ) is the fertile amphiploid obtained after chromosome doubling of hybrids between Hordeum chilense and durum wheat. Approaches used in the improvement of this crop have included crosses with hexaploid wheat to promote $\mathrm{D} / \mathrm{H}^{\mathrm{ch}}$ chromosome substitutions. While this approach has been successful as was the case with triticale, it has also complicated the genetic composition of the breeding materials. Until now tritordeum lines were analyzed based on molecular cytogenetic techniques and screening with a small set of DNA markers. However, the recent development of DArT markers in $\mathrm{H}$. chilense offers new possibilities to screen large number of accessions more efficiently.

Results: Here, we have applied DArT markers to genotype composition in forty-six accessions of hexaploid tritordeum originating from different stages of tritordeum breeding program and to $\mathrm{H}$. chilense-wheat chromosome addition lines to allow their physical mapping. Diversity analyses were conducted including dendrogram construction, principal component analysis and structure inference. Euploid and substituted tritordeums were clearly discriminated independently of the method used. However, dendrogram and Structure analyses allowed the clearest discrimination among substituted tritordeums. The physically mapped markers allowed identifying these groups as substituted tritordeums carrying the following disomic substitutions (DS): DS1D $\left(1 \mathrm{H}^{\mathrm{ch}}\right)$, DS2D $\left(2 \mathrm{H}^{\mathrm{ch}}\right)$, DS5D $\left(5 \mathrm{H}^{\mathrm{ch}}\right), \mathrm{DS} 6 \mathrm{D}\left(6 \mathrm{H}^{\mathrm{ch}}\right)$ and the double substitution DS2D $\left(2 \mathrm{H}^{\mathrm{ch}}\right), \mathrm{DS} 5 \mathrm{D}\left(5 \mathrm{H}^{\mathrm{ch}}\right)$. These results were validated using chromosome specific EST and SSR markers and GISH analysis.

Conclusion: In conclusion, DArT markers have proved to be very useful to detect chromosome substitutions in the tritordeum breeding program and thus they are expected to be equally useful to detect translocations both in the tritordeum breeding program and in the transference of $\mathrm{H}$. chilense genetic material in wheat breeding programs.
\end{abstract}

Keywords: Tritordeum, DArT, Chromosome substitution, GISH, EST, SSR markers

\section{Background}

Interspecific and intergeneric hybridization is a useful tool in the breeding of cultivated species of Triticeae tribe. This technique has been widely used to transfer desirable traits from wild to cultivated species [1-3] and to increase the genetic variation of the species by developing new synthetic hexaploid wheats [4-6] or using

\footnotetext{
* Correspondence: sgatienza@ias.csic.es

${ }^{1}$ Instituto de Agricultura Sostenible, IAS-CSIC, Apdo. 4084, Córdoba E-14080, Spain

Full list of author information is available at the end of the article
}

Triticum urartu (donor of the A genome) for durum wheat breeding [7]. Intergeneric hybrids between Hordeum and Triticum genus were attempted since the beginning of the $20^{\text {th }}$ century. Since the first hybrids reported by [8] numerous hybrid combinations between both genera have been produced and reviewed by [9]. However, only a few fertile hybrids have been obtained by chromosome doubling with colchicine. These were the hybrids between T. timopheevii $\times H$. bogdanii [10], $H$. chilense $\times T$. aestivum [11] and $H$. chilense $\times T$. durum [12]. Among Hordeum species, Hordeum chilense
C Biomed Central 
Roem. et Schultz. is a native South American diploid perennial wild barley $(2 \mathrm{n}=2 \mathrm{x}=14)$, included in the section Anisolepsis [13]. It belongs to a heterogeneous group of South American Hordeum species and it is one of the species of the genus Hordeum with a high potential for cereal breeding purposes, given its high crossability with other members of the Triticeae tribe and other interesting characteristics [14]. In recent years, molecular and cytological techniques have been developed in $H$. chilense for basic cytogenetic research, genetic diversity studies and monitoring $H$. chilense chromosomes in wheat genetic background. Several types of molecular markers, including Random Amplified Polymorphic DNA (RAPD) [15], Sequence Characterized Amplified Regions (SCARs) [16], Cleaved Amplified Polymorphisms (CAPs) [17] or DArTs [18] have been developed de novo for $H$. chilense. Similarly other markers have been transferred from wheat and barley species including Sequence Tagged Sites (STSs) [19], genomic or ESTderived simple sequence repeat (SSRs) [20,21], ESTs [22-24] or Conserved Orthologus Sequences (COS) [18].

In addition to marker-assisted selection, genomic in situ hybridization (GISH) and fluorescence in situ hybridization (FISH) are useful tools which have been used for identifying $H$. chilense chromosomes (or chromosome translocation) in wheat background [25-27].

Tritordeums ( $\times$ Tritordeum Ascherson et Graebner) are the fertile amphiploids obtained after chromosome doubling of hybrids between wheat (Triticum sp.) and $H$. chilense. They have been synthesised at different ploidy levels and genome constitutions, of which hexaploids tritordeums $\left(2 \mathrm{n}=6 \mathrm{x}=42, \mathrm{AABBH}^{\mathrm{ch}} \mathrm{H}^{\mathrm{ch}}\right)$ have been subject of breeding program [28]. The favourable agronomic traits shown by tritordeums, such as high biomass yield, number of spikelets/spike, seed size and high protein content, suggested its potential to become a new crop [29] which was confirmed nearly two decades later [30]. The high seed carotenoid content [31,32] of this species constitutes also an interesting characteristic in the context of developing functional foods. Accordingly, tritordeum has received attention as a potential crop in the last years and a breeding program has been developed including the development of chromosome substitutions involving $\mathrm{D}$ and $\mathrm{H}^{\mathrm{ch}}$ genomes. While the chromosome substitution program has obtained successful results for free threshing ability [33] or improved bread-making quality [34], it has also complicated the genetic composition of breeding materials since different chromosome substitutions may be present involving D and $\mathrm{H}^{\text {ch }}$ genomes. Until now tritordeum lines were inspected for $H$. chilense/wheat substitutions using physically mapped markers per chromosome [33] and using cytogenetics tools like GISH [22,24] and FISH [35]. While cytogenetics is useful for a limited set of lines, it is impractical for large amounts of entries included in a breeding program. Furthermore, the use of a limited number of molecular markers is not adequate for managing a large collection of germplasm since the rate of error in classification may be too high compared to whole genome profiling.

Based on the above considerations we embarked on development of Diversity Arrays Technology (DArT) since this technology can overcome these constraints. In addition DArT technology offers low cost per data, high throughput and sequence-independent genotyping [36,37] and allows simultaneously determination of several hundred to several thousands of polymorphic loci spread over the genome [38]. The high number of DArT markers generated in a single assay not only provides a precise estimate of genetic relationships among genotypes, but also their distribution over the genome offers real advantages for a range of molecular breeding and genomics applications.

DArT markers have been developed in more than 70 species (www.diversityarrays.com), including cereals such as cultivated barley (Hordeum vulgare), wheat (Triticum aestivum), durum wheat (Triticum durum), and recently wild barley (H. chilense).

DArT array have also been proved useful for polyploidy species with highly complex genomes [39]; to provide a fast and accurate means of determining the extent of introgression of the genome of the diverse parent in interespecific hybrids [40] or to evaluate progenies derived from interespecific crosses between $T$. aestivum and T. durum [41].

This paper evaluates the effectiveness of DArT as a high-throughput genotyping technology in tritordeum. This technology offers tritordeum breeding program an alternative approach to whole-genome profiling providing high quality markers that can be exploited in a range of molecular breeding and genomics applications in tritordeum. Additionally we set out to explore the possibility of using DArT array for genome background screening in tritordeum and to determine terms of discriminative ability using $1 \mathrm{RS} / 1 \mathrm{BL}$ translocation lines.

\section{Results}

\section{DArT array composition}

A total of 2,372 out of 11,000 new DArT clones generated previously from $H$. chilense [18] were printed in the array together with clones derived from other species developed in parallel projects $(2,071$ hexaploid wheatderived markers, 290 from $H$. vulgare, 208 from triticale and rye). From 4,941 clones identified on the array, a set of 3,357 markers were selected following the quality criteria explained above ( $\mathrm{P}$ value and reproducibility), with 2,377 polymorphic markers used for diversity analyses of the 46 tritordeum lines (Additional file 1). 
Wheat $H$. chilense chromosome addition lines allowed the physical location of a total of 2,209 $\mathrm{H}$. chilense-derived markers. Out of these, 1,280 markers could be assigned to a specific $H$. chilense chromosome on basis of two replicates (Additional file 2). The remainder could not be assigned because a) they were also present in genomic representations generated from wheat; $b$ ) they were absent in representations generated from $\mathrm{H} 1$, the accession used to develop $H$. chilense-wheat addition lines; c) they were found in $\mathrm{H} 1$ and absent in all the addition lines which suggests that these markers are located in either $2 \mathrm{H}^{\text {ch }} \mathrm{L}$ or $3 \mathrm{H}^{\mathrm{ch}}$, since addition lines carrying these chromosomes are not available or d) because they gave signal in two chromosomes and they were excluded of the study.

A subset of 450 DArT markers was shared with our mapping project [18], where Diversity Arrays technology (DArT) genomic libraries were developed from $H$. chilense accessions. Out of these, 378 physically mapped to a specific $H$. chilense chromosome matched the quality criteria in the present work.

\section{Genetic analysis}

PIC ranged from 0.04 to 0.5 , with an average of 0.31 , for a bi-allelic marker, the minimum and maximum PIC values are 0 and 0.5 , respectively. Two analyses were performed. The first of them included all the DArT markers while the second used polymorphic markers derived from $H$. chilense and D-genome, since we were looking for $\mathrm{H}^{\mathrm{ch}} / \mathrm{D}$ chromosomes substitutions. The latter analyse produced a better discrimination among tritordeum lines and thus only results obtained using this subset of markers are shown. Brieftly, both the dendrogram and the PCoA analyses obtained with all markers included two non-substituted tritordeums with the substituted ones. Besides, the structure analysis separated between the substituted tritordeums and nonsubstituted ones. However, further analysis was required to differentiate among the different substitions and it was unable to distinguish the DS6D $\left(6 \mathrm{H}^{\text {ch }}\right)$ and other substitutions.

First, the 1,145 polymorphic markers derived from $H$. chilense and wheat D genome were considered to construct a dendrogram (Figure 1). The accessions were separated into two major clusters with a cophenetic correlation value of 0.912 indicating an excellent fit of the similarity matrix data to the tree topology. The first group was formed by 27 accessions and it included those tritordeums with complete chromosome composition

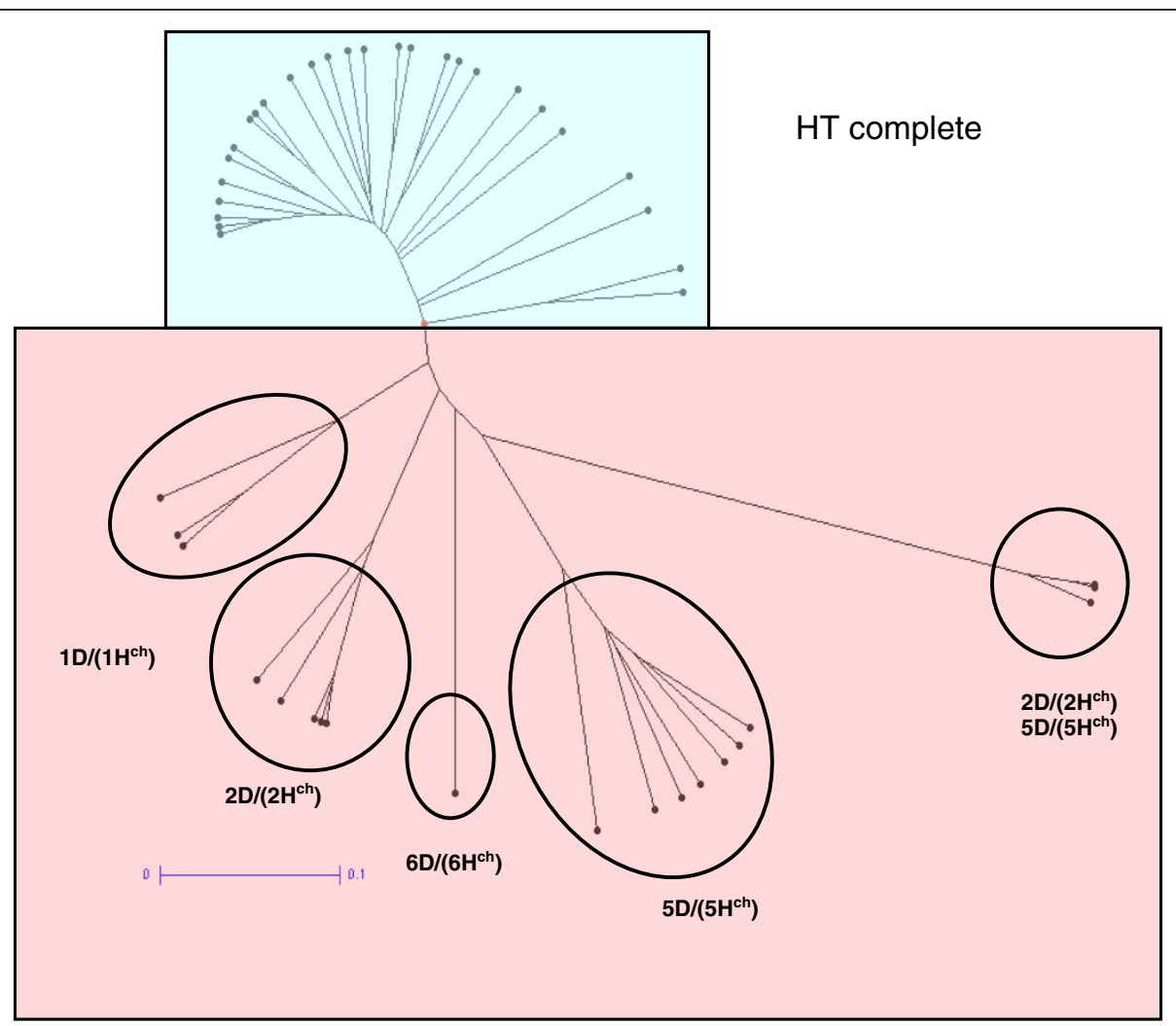

Figure 1 UPGMA dendrogram (shown as Radial tree). UPGMA dendrogram based on 1,145 H. chilense and D-genome polymorphic DArT markers using Jaccard's similarity matrix, showing the relationship between 46 tritordeum lines. Scale bar represent the genetic distance as determined using the Jaccard coefficient. 
and the second group clustered 19 accessions carrying suspected or known chromosomal substitutions. Within this latter group, the inspection of the DArT markers dataset allowed to assign each subgroup to a different chromosome substitution. Five subgroups were differentiated, four of them comprised a single chromosome substitution (DS1D $\left(1 \mathrm{H}^{\mathrm{ch}}\right)$, DS2D $\left(2 \mathrm{H}^{\mathrm{ch}}\right)$, DS5D $\left(5 \mathrm{H}^{\mathrm{ch}}\right)$ and DS6D $\left.\left(6 \mathrm{H}^{\mathrm{ch}}\right)\right)$ and one group had three genotypes with double chromosome substitution (DS2D $\left(2 \mathrm{H}^{\mathrm{ch}}\right)$ and $\left.\operatorname{DS} 5 \mathrm{D}\left(5 \mathrm{H}^{\mathrm{ch}}\right)\right)$ (Figure 1).

The principal coordinate (PCoA) was also constructed based on genotype data from the polymorphic DArT markers derived from $H$. chilense and wheat $\mathrm{D}$ genome. A two dimensional scatter plot of the 46 tritordeum genotypes, shown in Figure 2, confirmed the five different subgroups found by UPGMA dendrogram although the DS6D $\left(6 \mathrm{H}^{\mathrm{ch}}\right)$ and the DS1D $\left(1 \mathrm{H}^{\mathrm{ch}}\right)$ substitution were placed near the non-substituted tritordeums. The two first dimensions of PCoA explained $34 \%$ and $25 \%$ respectively of the variation present in the genetic distance calculated between genotypes. Again, tritordeums carrying $\mathrm{D} / \mathrm{H}^{\mathrm{ch}}$ substitutions were clearly differentiated from non-substituted tritordeums (Figure 2).

Genetic structure analysis detected an underlying structure, with six groups, based on the criterion of maximization of the natural log probability of the data, which is proportional to the posterior probability of $\mathrm{K}$ [42]. The results pointed out to a clear cut-off point for the number of groups in our sample for $\mathrm{K}=6$ (Figure 3a).
The genotypes were spread among the six groups as follows: Group I comprised 27 genotypes, including all tritordeums with complete chromosome composition, Group II includes three accessions from double chromosome substitution DS5D $\left(5 \mathrm{H}^{\mathrm{ch}}\right)$ and DS2D $\left(2 \mathrm{H}^{\mathrm{ch}}\right)$, Group III comprised three genotypes from DS1D $\left(1 \mathrm{H}^{\mathrm{ch}}\right)$ chromosome substitution, Group IV included one line from DS6D (6Hch) substitution, Group V had seven genotypes from the DS5D $\left(5 \mathrm{H}^{\mathrm{ch}}\right)$ chromosome substitution and group VI included five lines from the DS2D $\left(2 \mathrm{H}^{\mathrm{ch}}\right)$ chromosome substitution (Figure $3 \mathrm{~b}$ ).

The potential of DArT markers to detect translocations was studied on the basis of 114 polymorphic DArTs markers derived from rye and Triticale. PCoA analysis of these markers which revealed a clear discrimination between $1 \mathrm{RS} / 1 \mathrm{BL}$ and non-1RS/1BL translocation lines (Figure 4). Once we confirmed the 1RS/1BL translocation with the specific primers for the locus SEC$1 \mathrm{~b}$, we inspected the DArT data file to identify markers discriminating the eighteen tritordeum lines carrying the 1RS/1BL translocation. Thirty three markers were only present in the tritordeums with the translocation 1RS/1BL (Additional file 3). Most of them (31) were derived from rye or triticale and out of these; twenty eight were previously assigned to chromosome 1B and three not assigned to any chromosome. In addition, a single marker from each wheat $(1 \mathrm{~B})$ and barley $(1 \mathrm{H})$ also discriminated between translocated and non-translocated lines. Similarly, chromosome specific EST and SSR specific markers

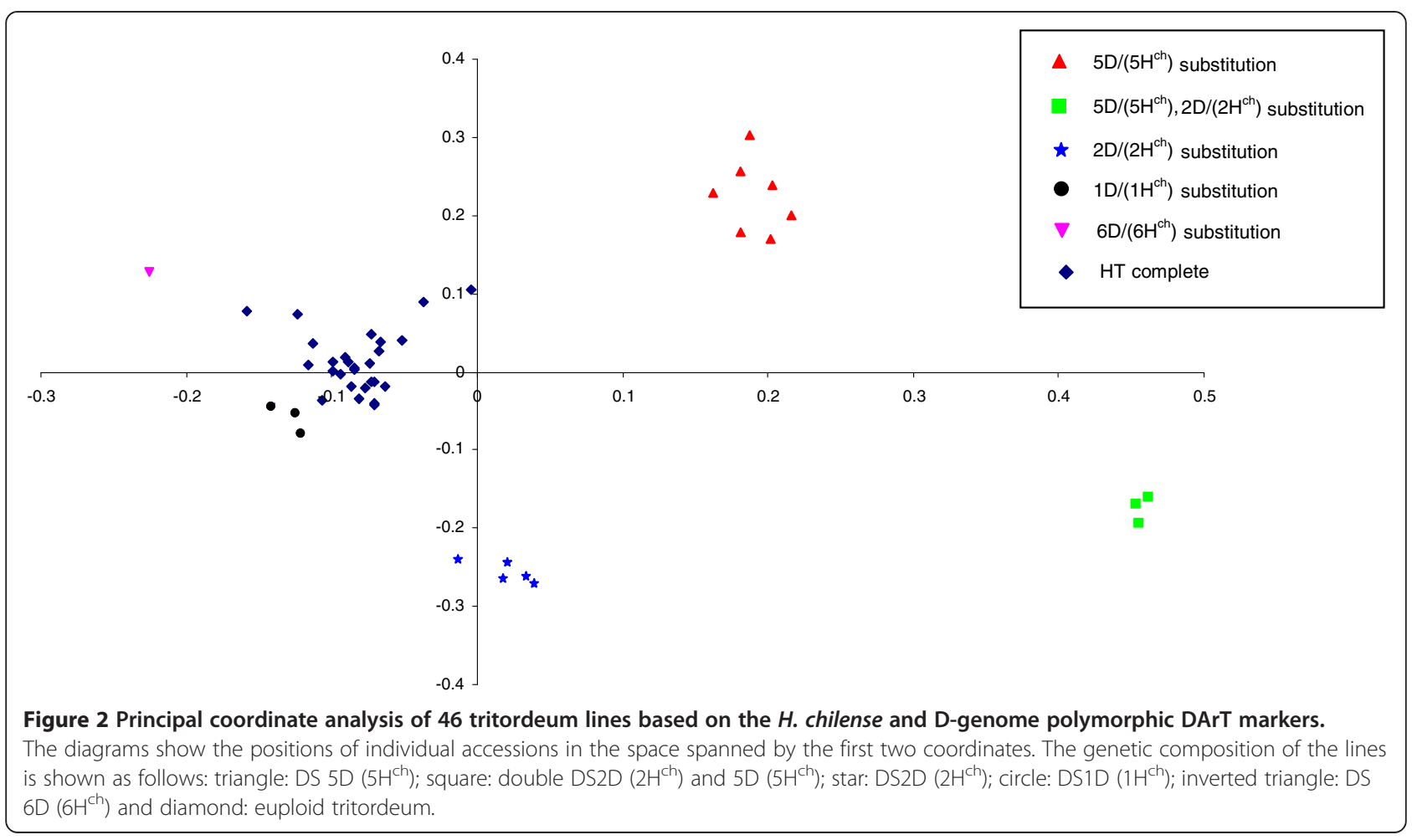




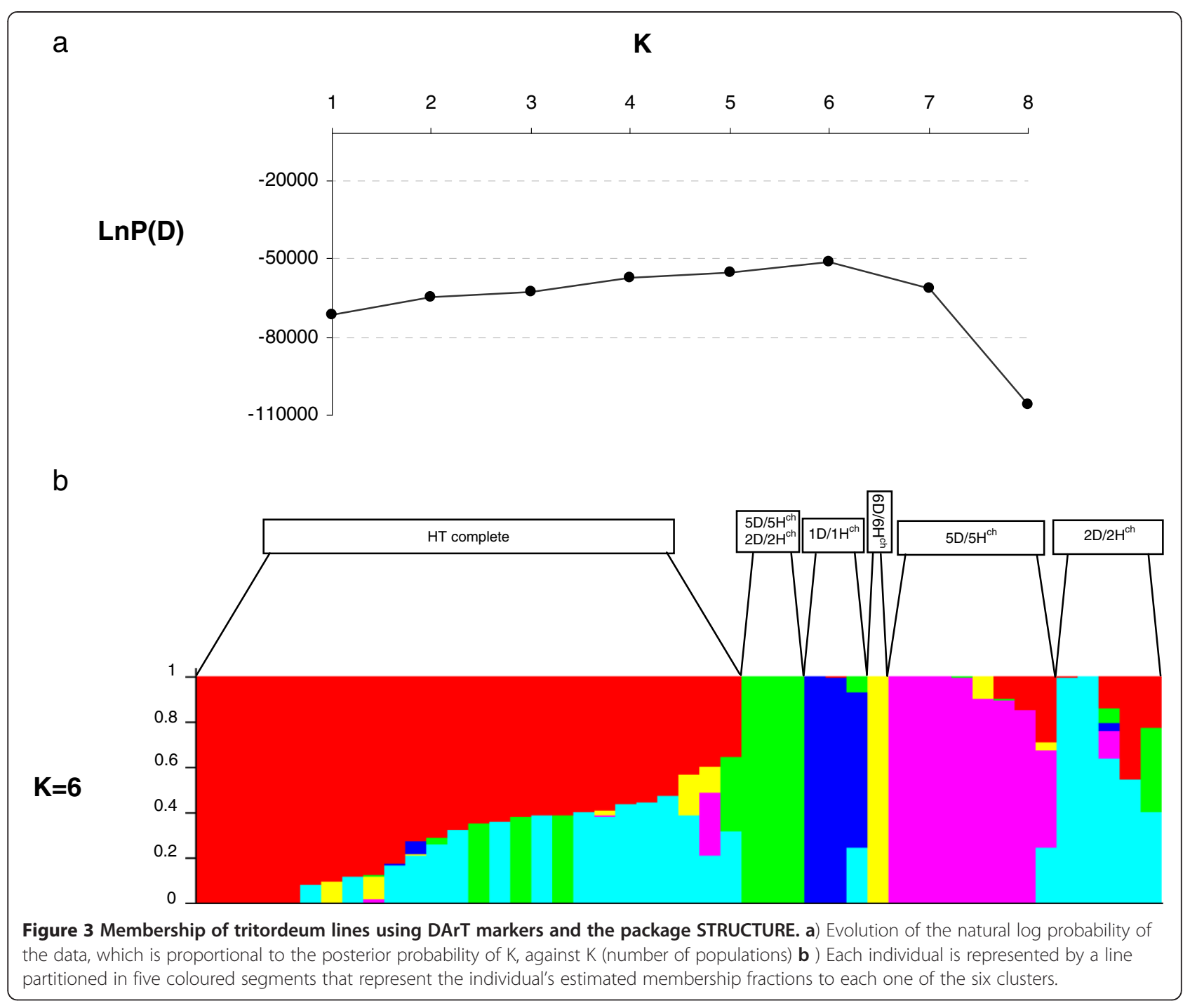

(Table 1) were used to verify the chromosome composition of the different lines studied. These markers either produce different amplification products in $H$. chilense and wheat or exclusively amplify the $H$. chilense genome, being therefore useful to detect chromosome substitutions.

\section{Cytogenetic characterization by GISH}

Genomic in situ hybridization was used to assess the chromosome substitutions using $H$. chilense genomic DNA as probe (detected with biotin). Sixteen single chromosome substitution lines were found to have only 12 chromosomes from $H$. chilense corresponding with DS1D $\left(1 \mathrm{H}^{\mathrm{ch}}\right)$, DS2D $\left(2 \mathrm{H}^{\mathrm{ch}}\right)$, DS5D $\left(5 \mathrm{H}^{\mathrm{ch}}\right)$ and DS6D $\left(6 \mathrm{H}^{\mathrm{ch}}\right)$ while three double chromosome substitution lines corresponding to DS2D $\left(2 \mathrm{H}^{\mathrm{ch}}\right)$ and DS5D $\left(5 \mathrm{H}^{\mathrm{ch}}\right)$ showed 10 chromosomes from $H$. chilense (Figure 5). The rest of the lines were unsubstituted tritordeums carrying all fourteen $H$. chilense chromosomes. In addition, eighteen lines showing $1 \mathrm{RS} / 1 \mathrm{BL}$ translocations were detected using S. cereale genomic DNA as probe (data not shown).

\section{Discussion}

The availability of reliable molecular markers is of great importance for plant breeding. The ideal molecular marker technique should generate hundreds of molecular markers that cover the entire genome in a single, simple and reliable experiment [43]. Genome-wide molecular markers are used for germplasm characterization, assessment of genetic diversity, to accelerate introgression or backcrossing programs, and for the mapping of complex traits. The high number of DArT markers generated in a single assay covering the whole genome allows the screening of a large number of genotypes in a rapid and efficient way.

Previous characterizations of the tritordeum have relied on cytogenetics using GISH and PCR-based markers $[33,34]$. The GISH technique is laborious and unsuitable 


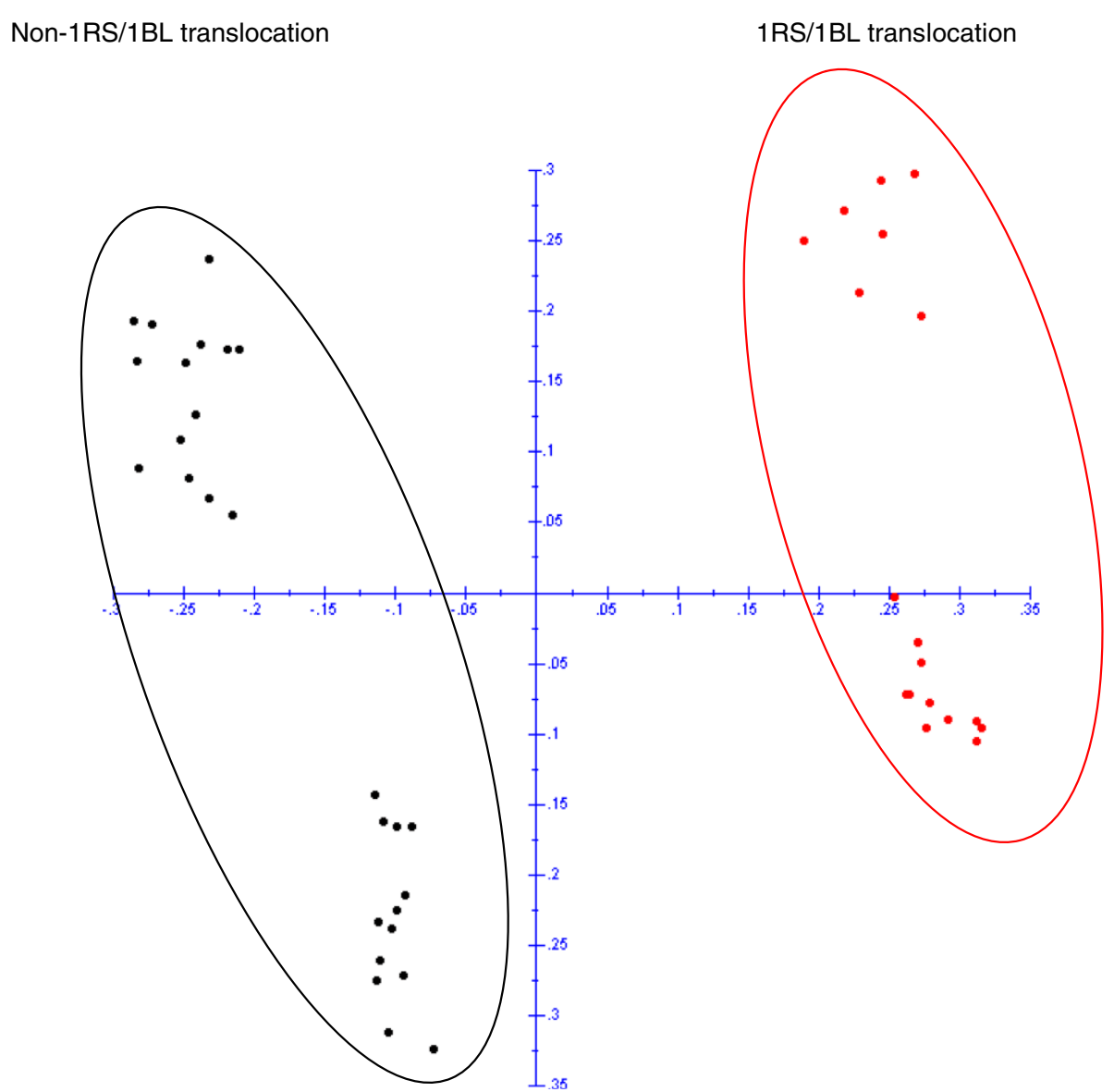

Figure 4 Principal coordinate analysis of 46 tritordeum lines based on all the rye and triticale polymorphic DArT markers regardless their chromosome position.

for high-throughput analyses. Similarly, the use of small sets of molecular markers may fail to detect translocations between $\mathrm{H}^{\mathrm{ch}}$ and $\mathrm{D}$ genomes in a high proportion and thus they only partially fulfil the requirements of our research programs. The development of DArT markers in $H$. chilense has facilitated the use of these markers in tritordeum breeding program and related projects. In this work, we took advantage of the existence of a large number of DArT markers previously developed from hexaploid wheat, $H$. vulgare, Triticale, $S$. cereale and $H$. chilense. A high percentage of DArT markers (48\%) were polymorphic among the accessions studied which is higher than observed for DArT in other crops. For example a polymorphism rate of $9.4 \%$ observed in wheat [39] while the polymorphism rate for DArT markers originating from hexaploid wheat, triticale, and rye as $8.6 \%, 23.4 \%$ and $23.8 \%$, respectively in triticale [44]. Since the DArT array was designed to maximize polymorphism rate considering previous experiments, this has resulted in a much higher polymorphism rate than reported in other crops. The average PIC value of 0.31 found in the current study was informative and comparable to values previously observed for barley (0.38) [38], wheat (0.31) [39], hop (0.34) [45], and triticale (0.37) [44].

$H$. chilense and D-genome polymorphic markers were selected for genetic analysis to increase the power of detection of chromosome substitutions involving these genomes.

All three diversity analyses showed a good level of consistence to discriminate between substituted and non-substituted tritordeums. Both the dendrogram and the structure analysis grouped separately each type of chromosome substitutions but the first is much faster. Finally, the PCoA analysis discriminated well among groups. However, the DS6D $\left(6 \mathrm{H}^{\mathrm{ch}}\right)$ and the DS1D $\left(1 \mathrm{H}^{\mathrm{ch}}\right)$ groups appeared closely to non-substituted tritordeums which might lead to errors in classification in future analyses. In any case, we think that the application of DArT to the tritordeum breeding program would benefit from the analysis with all three methodologies since lines grouped differently in different methodologies may require a deeper analysis of the results.

The development of substitution lines has proven to be an efficient tool for the improvement of important 
Table 1 Description of PCR-based markers used for the characterization of tritordeum lines

\begin{tabular}{ll}
\hline a) & \\
EST-markers (Nasuda et al. [24]) & Chromosomal location \\
\hline$k 01339$ & $1 H^{c h} S$ \\
$k 01437$ & $1 H^{c h} L$ \\
$k 04721$ & $2 H^{c h} S$ \\
$k 00579$ & $2 H^{c h} L$ \\
$k 02539$ & $4 H^{c h} S$ \\
$k 04725$ & $4 H^{c h} L$ \\
$k 01323$ & $5 H^{c h} S$ \\
$k 04947$ & $5 H^{c h} L$ \\
$k 01062$ & $6 H^{c h} S$ \\
$k 01193$ & $6 H^{c h} L$ \\
$k 04783$ & $7 H^{c h} S$ \\
$k 04058$ & $7 H^{c h} L$
\end{tabular}

b)

SSR-markers (Röder et al. [53])

Xgwm337

Chromosomal location

Xgwm261 2D

Xgwm161 3D

Xgwm194 4D

Xgwm272 5D

Xgwm325 6D

Xgwm44 7D

a) Barley EST-SSR markers previously assigned to $H$. chilense chromosomes, b) D-genome specific SSR markers.

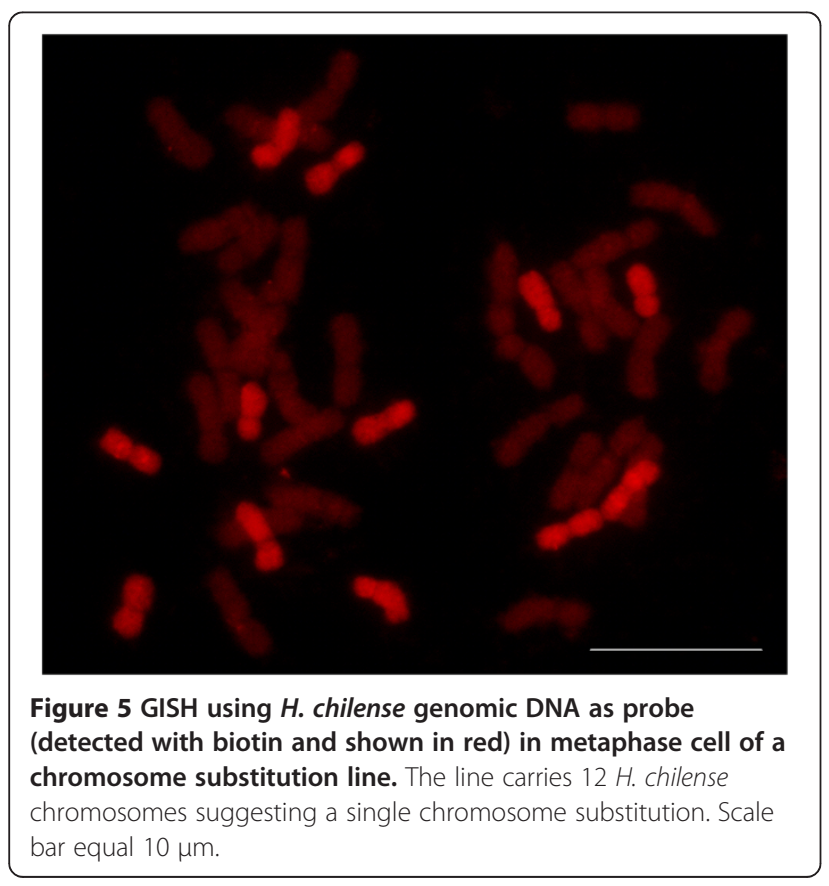

agronomic traits. For instance, a major contribution to triticale improvement was achieved by the use of 'Armadillo,' a line showing improved fertility due to the chromosome substitution DS2D (2R) [46]. Although subsequent international yield trials indicated that complete hexaploid triticales showed a better agronomic performance than substitutes [47], the contribution of Armadillo to triticale improvement was very important. Similarly, $\mathrm{D} /\left(\mathrm{H}^{\mathrm{ch}}\right)$ substitutions have allowed the improvement of breadmaking quality [34] or free-threshing ability [33] but it is expected that tritordeums without chromosome substitutions will show superior performance over substituted ones in the future, as was observed in triticale. Nevertheless, the occurrence of translocations involving $\mathrm{H}^{\text {ch }}$ and $\mathrm{D}$ chromosomes may still add interesting characteristics, as seen in wheat. Indeed, the $1 \mathrm{RS} / 1 \mathrm{BL}$ translocation is one of the most frequently used alien introgresions in wheatbreeding programs throughout the world [48]. The 1RS/ 1BL has positive effect on agronomic traits like yield performance, however, 1RS carries the Sec-1 locus coding for $\varepsilon$-secalin, which results in negative effects on breadmaking quality. DArT markers clearly discriminated the lines with the $1 \mathrm{RS} / 1 \mathrm{BL}$ translocation and thus, it is expectable that they will also allow the detection of $\mathrm{D} /\left(\mathrm{H}^{\mathrm{ch}}\right)$ translocations when available. Accordingly these markers will prove very useful in parallel ongoing projects such as the development of hybrid wheat [49-51].

\section{Conclusions}

In conclusion, DArT markers allowed discrimination of the substitution lines involving the $\mathrm{D}$ genomes $/ \mathrm{H}^{\mathrm{ch}}$. All three methodologies clearly separated complete from substituted tritordeums but the combination between them will allow better discrimination of the specific lines. DArT markers also allowed the detection of translocations as evidenced from by the study of the 1RS/1BL translocation and, thus, they will very useful both in the tritordeum breeding program and the common wheat hybrid system.

\section{Methods}

\section{Plant material}

Forty-six accessions of hexaploid tritordeum originating from different stages of tritordeum breeding program were evaluated. Triticum aestivum cv. Chinese Spring (CS)- $H$. chilense addition lines for complete chromosomes $1 \mathrm{H}^{\text {ch }}, 4 \mathrm{H}^{\text {ch }}, 5 \mathrm{H}^{\mathrm{ch}}, 6 \mathrm{H}^{\text {ch }}$ and $7 \mathrm{H}^{\text {ch }}$ (named CS MA $1 \mathrm{H}^{\mathrm{ch}}-1 \mathrm{H}^{\mathrm{ch}} \mathrm{S}$, CS DA4 $4 \mathrm{H}^{\mathrm{ch}}$, CS DA5 $\mathrm{H}^{\mathrm{ch}}$, CS DA6 $\mathrm{H}^{\mathrm{ch}}$ and CS $\mathrm{DA} 7 \mathrm{H}^{\mathrm{ch}}$, respectively, where MA refers to monosomic addition and DA means disomic addition), and the wheat-(CS)- $H$. chilense ditelosomic addition lines CS DA $1 \mathrm{H}^{\mathrm{ch}} \mathrm{S}, \mathrm{CS}$ DA2 $\mathrm{H}^{\mathrm{ch}} \mathrm{S}, \mathrm{CS}$ DA5 $\mathrm{H}^{\mathrm{ch}} \mathrm{L}, \mathrm{CS} \mathrm{DA} 6 \mathrm{H}^{\mathrm{ch}} \mathrm{S}, \mathrm{CS}$ DA7H ${ }^{\text {ch }} \alpha, C S D A 7 H^{\text {ch }} \beta$ were used to assign markers to specific chromosomes. T. aestivum cv 'Chinese Spring' 
and $H$. chilense accession $\mathrm{H} 1$ were also included. DNA was extracted from young leaf tissue from a single plant of each genotype using the protocol recommended by Triticarte Pty. Ltd. (http://www.triticarte.com.au).

\section{Genotyping}

A total of 4,941 DArT clones were printed in the array. Most of them were derived from $H$. chilense $(2,372)$ and hexaploid wheat $(2,071)$. The array was completed with markers from barley (290) and rye and triticale (208). The resulting composite array was then used to fingerprint tritordeum and addition lines using the standard DArT protocol [52]. Only DArT markers with a quality criteria, $\mathrm{P}$ value and reproducibility higher than 80 and 97\% respectively, were selected.

Polymorphism information content (PIC), a measure of the informativeness of a genetic marker, was also calculated for each marker as follows; $\mathrm{PIC}=1-\Sigma \mathrm{Pi}^{2}$, where $\mathrm{Pi}$ is the frequency of the $i$ th allele in the examined genotypes. Chromosome substitutions in tritordeum were verified as previously described [33]. A set of Expressed sequence tagged (EST) markers [23,24] and wheat chromosome-specific SSRs [53] were used to verify the presence of $H$. chilense and wheat chromosomes respectively (Table 1). 1RS/1BL translocations were detected using the primer pair SecA2/SecA3 designed specifically to amplify a sequence of $\omega$-secalin gene (locus SEC-1b) located on the short arm of the rye chromosome 1R [54].

\section{Data analysis}

The data matrix containing the $0 / 1$ scores of the $H$. chilense and D-genome-derived polymorphic DArT markers was transformed to a genetic distance matrix using Jaccard's coefficient [55]. The genetic distance matrix was used to produce an unrooted Unweighted Pair Group Method with Algorithmic Mean (UPGMA) dendrogram using the program Dissimilarity Analysis and Representation for Windows, also known as DARwin [56]. Also, the first two principal coordinates of the resulting Jaccard matrix were extracted to display the position of the accessions in a two-dimensional space (as an indication of the diversity of each pair of the accessions). Similarly, PCoA analysis was employed using polymorphic markers from rye and triticale genome.

Model-based clustering, employing a Bayesian algorithm, was applied to infer the genetic structure of the 46 tritordeum accessions using STRUCTURE software version 2.3.1 [57]. The program was run assuming a population admixture model and correlated allele frequencies. The number of assumed groups (K) was set to vary between 1 and 10 , and for each value of $K$ five times independently MCMC (Markov Chain Monte Carlo) of 50,000 iterations was run in order to verify that the estimates were consistent across runs, of which the first 10,000 were discarded as burn-in. The likelihood of the data for a given number of assumed groups (K) is provided by the software, and the value of $\mathrm{K}$ with the highest likelihood can be interpreted to correspond to an estimate for the underlying number of groups. Within the admixture model we can obtain the membership probabilities of each genotype to each group inferred.

\section{Genomic in situ hybridization (GISH)}

Root tips of 1-cm length were collected from germinating seeds and pre-treated for $4 \mathrm{~h}$ in an aqueous colchicine solution $(0.05 \%)$ at $25^{\circ} \mathrm{C}$. They were fixed in a freshly prepared 3 absolute ethanol: 1 glacial acetic acid $(v / v)$ mixture and stored at $4^{\circ} \mathrm{C}$ during 1 month approximately. Preparations were made as described by [58]. Total $H$. chilense genomic DNA was labelled by nick translation with biotin-11-dUTP (Roche Corporation, Basel, Switzerland) and total Secale cereale genomic DNA was labelled with digoxigenin-dUTP. Both probes were mixed in the hybridization solution to a final concentration of $5 \mathrm{ng} / \mathrm{ml}$. Biotin- and digoxigenin-labelled probes were detected with streptavidin-Cy3 conjugates (Sigma, St Louis, MO, USA) and antidigoxigenin-FITC (Roche Corporate) respectively. Chromosomes were counterstained with DAPI (4', 6-diamidino-2-phenylindole) and mounted in Vectashield (Vector Laboratories Inc.). Slides were examined by using a Zeiss LSM 5 Pa confocal laser scanning microscope with LSM 5 Pascal software version 3.0 (Zeiss, Jena, Germany).

\section{Additional files}

Additional file 1: Polymorphic markers found among 46 tritordeum accessions. $H$. chilense and D- genome markers used for genetic analysis are shown in bold.

Additional file 2: Markers assigned to a specific $H$. chilense chromosome using wheat- $H$. chilense addition lines.

Additional file 3: Markers discriminating tritordeums carrying the 1RS/1BL translocation.

\section{Competing interests}

The authors declare that they have no competing interests.

\section{Authors' contributions}

AC performed SSR, EST and GISH genotyping, data analysis, interpretation of results and paper writing. MCR participated in chromosome counting, GISH genotyping and plant material development. ACM participated in SSR, EST and GISH genotyping. AK participated in the DArT genotyping. AM developed all the plant materials, conception, design of the study and interpretation of the results. SGA participated in design of the study, data analysis, interpretation of results and paper writing. All authors read and approved the final manuscript.

\section{Acknowledgments}

This research was supported by grants AGL2009-11359 and 2008401137 from the Ministerio de Economía y Competitividad, CSIC and FEDER. This work is included within the CSIC - Agrasys SL collaboration agreement for the development of tritordeum. 


\section{Author details}

${ }^{1}$ Instituto de Agricultura Sostenible, IAS-CSIC, Apdo. 4084, Córdoba E-14080, Spain. ${ }^{2}$ Diversity Arrays Technology Pty Ltd, PO Box 7141, Yarralumla, ACT 2600, Australia.

Received: 16 January 2013 Accepted: 27 May 2013

Published: 3 June 2013

\section{References}

1. Friebe B, Jiang J, Raupp WJ, McIntosh RA, Gill BS: Characterization of wheat-alien translocations conferring resistance to diseases and pests: current status. Euphytica 1996, 91:59-87.

2. Jiang J, Friebe B, Gill BS: Recent advances in alien gene transfer in wheat. Euphytica 1994, 72:199-212.

3. Jones SS, Murray TD, Allan RE: Use of alien genes for the development of disease resistance in wheat. Annu Rev Phytopathol 1995, 33:429-443.

4. Mares D, Mrva K: Genetic variation for quality traits in synthetic wheat germplasm. Aust J Agric Res 2008, 59:406-412.

5. Ogbonnaya FC, van Ginkel M, Brettell R: Preface: "Synthetics for Wheat Improvement". Proceedings of the 1st Synthetic Wheat Symposium, September 2006. Aust J Agric Res 2008, 59:389-390.

6. van Ginkel M, Ogbonnaya F: Novel genetic diversity from synthetic wheats in breeding cultivars for changing production conditions. Field Crops Res 2007, 104:86-94.

7. Rodríguez-Suárez C, Ramírez MC, Martín A, Atienza SG: Applicability of chromosome-specific SSR wheat markers for the introgression of Triticum urartu in durum wheat breeding programmes. Plant Genet Res Charact Utiliz 2011, 9:439-444.

8. Kruse A: Hordeum x Triticum hybrids. Hereditas 1973, 73:157-161.

9. Fedak G: Intergeneric hybrids with Hordeum. In Barley: Genetics, Biochemistry, Molecular Biology and Biotechnology. Edited by Shewry PR. Osford, UK: C.A.B. International, The Alden Press Ltd; 1992:45-68,

10. Kimber G, Sallee PJ: A trigeneric hybrid in the Triticeae. Cereal Res Commun 1979, 7:5-9.

11. Martin A, Chapman V: A hybrid between Hordeum chilense and Triticum aestivum. Cereal Res Commun 1977, 5:365-368.

12. Martín A, Sánchez-Monge Laguna E: Cytology and morphology of the amphiploid Hordeum chilense' Triticum turgidum conv Durum. Euphytica 1982, 31:261-267.

13. Bothmer R, Jacobsen N, Baden C, Jorgensen RB, Linde-Laursen I: An ecogeographical study of the genus Hordeum. Systematic and Ecogeographic Studies on Crop Genepools. 7. Rome, Italy: International Board of Plant Genetic Resources; 1995:129.

14. Rodríguez-Suárez C, Giménez MJ, Ramírez MC, Martín AC, Gutierrez N, Ávila CM, Martín A, Atienza SG: Exploitation of nuclear and cytoplasm variability in Hordeum chilense for wheat breeding. Plant Genet Res Charact Utiliz 2011, 9:313-316.

15. Hernández P, Rubio MJ, Martín A: Development of RAPD markers in tritordeum and addition lines of Hordeum chilense in Triticum aestivum. Plant Breed 1996, 115:52-56.

16. Hernández P, Martín A, Dorado G: Development of SCARs by direct sequencing of RAPD products: a practical tool for the introgression and marker-assisted selection of wheat. Mol Breed 1999, 5:245-253.

17. Atienza SG, Ávila CM, Martín A: The development of a PCR-based marker for Psy1 from Hordeum chilense, a candidate gene for carotenoid content accumulation in tritordeum seeds. Aust J Agric Res 2007, 58:767-773.

18. Rodríguez-Suárez C, Giménez MJ, Gutiérrez N, Ávila CM, Machado A, Huttner E, Ramírez MC, Martín A, Castillo A, Kilian A, et al: Development of wild barley (Hordeum chilense)-derived DArT markers and their use into genetic and physical mapping. Theor Appl Genet 2012, 124:713-722.

19. Hernández P, Hemmat M, Weeden NF, Dorado G, Martín A: Development and characterization of Hordeum chilense chromosome-specific STS markers suitable for wheat introgression and marker-assisted selection. Theor Appl Genet 1999, 98:721-727.

20. Castillo A, Budak H, Martín AC, Dorado G, Börner A, Röder M, Hernández P. Interspecies and intergenus transferability of barley and wheat D-genome microsatellite markers. Ann Appl Biol 2010, 156:347-356.

21. Castillo A, Budak H, Varshney R, Dorado G, Graner A, Hernández P: Transferability and polymorphism of barley EST-SSR markers used for phylogenetic analysis in Hordeum chilense. BMC Plant Biol 2008, 8:97.
22. Hagras AAA, Kishii M, Sato K, Tanaka H, Tsujimoto H: Extended application of barley EST markers for the analysis of alien chromosomes added to wheat genetic background. Breed Sci 2005, 55:335-341.

23. Hagras AAA, Kishii M, Tanaka H, Sato K, Tsujimoto H: Genomic differentiation of Hordeum chilense from $\mathrm{H}$-vulgare as revealed by repetitive and EST sequences. Genes Genet Syst 2005, 80:147-159.

24. Nasuda S, Kikkawa Y, Ashida T, Rafiqul Islam AKM, Sato K, Endo TR: Chromosomal assignment and deletion mapping of barley EST markers. Genes Genet Syst 2005, 80:357-366.

25. Cabrera A, Martín A: Cytology and morphology of the ampliploid Hordeum chilense (4x) x Aegilops squarrosa (4x). Theor Appl Genet 1991, 81:758-760

26. Cherif-Mouaki S, Said M, Alvarez JB, Cabrera A: Sub-arm location of prolamin and EST-SSR loci on chromosome $1 \mathrm{H}^{\mathrm{ch}}$ from Hordeum chilense. Euphytica 2011, 178:63-69

27. Said M, Cabrera A: A physical map of chromosome $4 \mathrm{H}(\mathrm{ch})$ from $\mathrm{H}$ chilense containing SSR, STS and EST-SSR molecular markers. Euphytica 2009, 167:253-259.

28. Martín A, Martínez C, Rubiales D, Ballesteros J: Tritordeum: triticale's new brother cereal. In Triticale: today and tomorrow. Edited by Güedes-Pinto $\mathrm{H}$, Darvey N, Carnide VP. Dordrecht, NL: Kluwer Academic Publishers; 1996:57-72.

29. Martín A, Cubero Jl: The use of Hordeum chilense in cereal breeding. Cereal Res Commun 1981, 9:317-323.

30. Martín A, Alvarez JB, Martín LM, Barro F, Ballesteros J: The development of tritordeum: a novel cereal for food processing. J Cereal Sci 1999, 30:85-95.

31. Atienza SG, Ballesteros J, Martín A, Hornero-Mendez D: Genetic variability of carotenoid concentration and degree of esterification among tritordeum (xTritordeum Ascherson et Graebner) and durum wheat accessions. J Agri Food Chem 2007, 55:4244-4251.

32. Ballesteros J, Ramírez MC, Martínez C, Atienza SG, Martín A: Registration of HT621, a high carotenoid content tritordeum germplasm line. Crop Sci 2005, 45:2662-2663.

33. Atienza SG, Martín AC, Martín A: Introgression of wheat chromosome 2D or $5 \mathrm{D}$ into tritordeum leads to free-threshing habit. Genome 2007 50:994-1000.

34. Ballesteros J, Ramírez MC, Martínez C, Barro F, Martín A: Bread-making quality in hexaploid tritordeum with substitutions involving chromosome 1D. Plant Breed 2003, 122:89-91.

35. Cabrera A, Friebe B, Jiang J, Gill BS: Characterization of Hordeum chilense chromosomes by C-banding and in situ hybridization using highly repeated DNA probes. Genome 1995, 38:435-442.

36. Jaccoud D, Peng K, Feinstein D, Kilian A: Diversity arrays: a solid state technology for sequence information independent genotyping. Nucleic Acid Res 2001, 29:e25.

37. Kilian A, Huttner E, Wenzl P, Jaccoud D, Carling J, Caig V, Evers M, HellerUszynska CC, Patarapuwadol S, Xia L, et al: The fast and the cheap: SNP and DArT-based whole genome profilling for crop improvement. In Proceedings of the international congress "In the wake of the double helix: from the green revolution to the gene revolution", 27-31 May, 2003. Edited by Tuberosa R, Philips RL, Gale M. Bologna, Italy: Avenue Media; 2005:443-461.

38. Wenzl P, Carling J, Kudrna D, Jaccoud D, Huttner E, Kleinhofs A, Kilian A: Diversity Arrays Technology (DArT) for whole-genome profiling of barley. P Natl Acad Sci USA 2004, 101:9915-9920.

39. Akbari M, Wenzl P, Caig V, Carling J, Xia L, Yang S, Uszynski G, Moheler V, Lehmensiek A, Kuchel $H$, et al: Diversity arrays technology (DArT) for highthroughput profiling of the hexaploid wheat genome. Theor Appl Genet 2006, 113:1409-1420.

40. Kopecký D, Bartos J, Christelová P, Cernoch V, Kilian A, Dolezel J: Genomic constitution of Festuca $\times$ Lolium hybrids revealed by the DArTFest array. Theor Appl Genet 2011, 122:355-363.

41. Eberhard FS, Zhang P, Lehmensiek A, Hare RA, Simpfendorfer S, Sutherland MW: Chromosome composition of an $\mathrm{F}_{2}$ Triticum aestivum $\times$ T. turgidum spp. durum cross analysed by DArT markers and MCFISH. Crop Pasture Sci 2010, 61:619-624.

42. Falush D, Stephens M, Pritchard JK: Inference of population structure using multilocus genotype data: linked loci and correlated allele frequencies. Genetics 2003, 164:1567-1587.

43. Luikart G, England PR, Tallmon D, Jordan S, Taberlet P: The power and promise of population genomics: from genotyping to genome typing. Nature Reviews Genetics 2003, 4:981-994. 
44. Badea A, Eudes F, Salmon D, Tuvesson S, Vrolijk A, Larsson CT, Caig V, Huttner E, Kilian A, Laroche A: Development and assessment of DArT markers in triticale. Theor Appl Genet 2011, 122:1547-1560.

45. Howard EL, Whittock SP, Jakse J, Carling J, Matthews PD, Probasco G, Henning JA, Darby P, Cerenak A, Javornik B, et al: High-throughput genotyping of hop (Humulus lupulus L.) utilising diversity arrays technology (DArT). Theor Appl Genet 2011, 122:1265-1280.

46. Zillinsky FJ: The development of triticale. Adv Agron 1974, 26:315-348.

47. Mergoum M, Pfeiffer WH, Peña RJ, Ammar K, Rajaram S: Triticale crop improvement: the CIMMYT programme. In Triticale Improvement and Production Plant Protduction and Protection Paper 179. Edited by Mergoum M, Gómez-Macpherson H. Rome: FAO; 2004:11-26.

48. Rabinovich SV: Importance of wheat-rye translocations for breeding modern cultivars of Triticum aestivum L. (Reprinted from Wheat: Prospects for global improvement, 1998). Euphytica 1998, 100:323-340.

49. Martín AC, Atienza SG, Ramírez M, Barro F, Martín A: Molecular and cytological characterization of an extra acrocentric chromosome that restores male fertility of wheat in the $\mathrm{msH} 1 \mathrm{CMS}$ system. Theor Appl Genet 2010, 121:1093-1101.

50. Martín AC, Atienza SG, Ramírez MC, Barro F, Martín A: Male fertility restoration of wheat in Hordeum chilense cytoplasm is associated with 6H(ch)S chromosome addition. Aust J Agric Res 2008, 59:206-213.

51. Martín AC, Atienza SG, Ramírez MC, Barro F, Martín A: Chromosome engineering in wheat to restore male fertility in the msH1 CMS system. Mol Breed 2009, 24:397-408.

52. Kilian A, Wenzl $P$, Huttner E, Carling J, Xia L, Blois H, Caig V, Heller-Uszynska CC, Jaccoud D, Hopper C, et al: Diversity arrays technology: a generic genome profiling technology on open platforms. Methods Mol Biol 2012 888:67-88.

53. Röder M, Korzun V, Wendehake K, Plaschke J, Tixier MH, Leroy P, Ganal MW: A microsatellite map of wheat. Genetics 1998, 149:2007-2023.

54. de Froidmont D: A co-dominant marker for the 1BL/1RS wheat-rye translocation via multiplex PCR. J Cereal Sci 1998, 27:227-232.

55. Jaccard P: Nouvelles recherches sur la distribution florale. Bull Soc Vand Sci Nat 1908, 4:223-270.

56. Perrier X, Flori A, Bonnot F: Data analysis methods. In Genetic diversity of cultivated tropical plants. Edited by Hamon P, Seguin M, Perrier X, Glaszmann JC. Enfield: Science Publishers, Monpellier; 2003:43-76.

57. Pritchard JK, Stepehns M, Donnelly P: Inference of population structure using multilocus genotype data. Genetics 2000, 155:945-959.

58. Prieto P, Ramírez MC, Ballesteros J, Cabrera A: Identification of intergenomic translocations involving wheat, Hordeum vulgare and Hordeum chilense chromosomes by FISH. Hereditas 2001, 135:171-174.

doi:10.1186/1471-2229-13-87

Cite this article as: Castillo et al: High-throughput genotyping of wheatbarley amphiploids utilising diversity array technology (DArT). BMC Plant Biology 2013 13:87.

\section{Submit your next manuscript to BioMed Central and take full advantage of:}

- Convenient online submission

- Thorough peer review

- No space constraints or color figure charges

- Immediate publication on acceptance

- Inclusion in PubMed, CAS, Scopus and Google Scholar

- Research which is freely available for redistribution 